Inna Fedotenko [Инна Федотенко]

ORCID: 0000-0003-1160-6334

Тульский государственный педагогический университет

им. Л.Н. Толстово, Тула, Россия

\title{
ПОДГОТОВКА БУДУЩИХ ПЕДАГОГОВ К ПРЕВЕНЦИИ ШКОЛЬНОГО НАСИЛИЯ В ИНКЛЮЗИВНОМ ОБРАЗОВАНИИ
}

\author{
Preparing future teachers for the prevention \\ of school violence in inclusive education
}

https://doi.org/10.34739/sn.2020.20.03

\begin{abstract}
Аннотация: В статье анализируются пути и средства подготовки бакалавров к превентивной профессиональной деятельности. Автор исследует теоретические и эмпирические аспекты превенции как психолого педагогического феномена. Раскрывается специфика школьного насилия в итуации инклюзии. Показаны возможности психолого-педагогических дисциплин и производственной практики в становлении превентивной позиции будущих учителей.
\end{abstract}

Ключевые слова: превентивная позиция, школьное насилие, кибербуллинг, инклюзивное образование, подгот овка, бакалавры, дети с особыми образовательными потребностями, тренинговые, игровые, проблемные, проектные технологии

\begin{abstract}
The article analyzes the ways and means of preparing bachelors for preventive professional activities. The author explores the theoretical and empirical aspects of prevention as a psychological and pedagogical phenomenon. The article reveals the specifics of school violence in the situation of inclusion. The possibilities of psychological and pedagogical disciplines and practical training in the formation of the preventive position of future teachers are shown.

Keywords: prevention, school violence, cyberbullying, inclusive education, training, bachelors, children with special educational needs, training, games, problem, and project technologies
\end{abstract}


Тенденция перманентного ухудшения состояния здоровья молодого поколения - это существенная характеристика современной социокультурной ситуации в России. Рост числа школьников с физическими или психическими проблемами очевиден для педагогов, психологов, родителей учащихся медицинского сообщества. Дети с особыми образовательными потребностями - это дети, имеющие временные или постоянные нарушения в физическом и (или) психическом развитии, которые нуждаются в создании специальных условий для получения образования.

Грамотно организованная инклюзия обеспечивает выигрыш не только детей с ограниченными возможностями здоровья, но и их здоровых сверстников. Ценность инклюзивных классов состоит в том, что они помогают сформировать у детей готовность жить в мультикультурном мире.

Современный период внедрения инклюзии в образовательные организации России - это «инклюзия без границ». У родителей целенаправленно создается положительное восприятие совместного обучения. Подобная поведенческая матрица доминирует сегодня в восприятии значительного большинства педагогов, психологов, социальных работников.

Учителя, школьные психологи, для которых ценности инклюзивного обучения не стали личностно значимыми, способны лишь формально выполнять организационные процедуры, разрушая своим профессиональным поведением сущность инклюзии. Положительный резонанс возможен только в том случае, если инклюзия принята профессиональным сообществом на уровне личностных смыслов, а не только специальных приемов и техник.

Вместе с тем, одновременно с популяризацией идеи инклюзии, нарастает латентное сопротивление со стороны школьных учителей. Среди объективных причин протестных настроений неготовность учителей к новому виду профессиональной деятельности и к новой ответственности. Для педагогов, родителей учеников, школьных психологов очевиден еще один негативный фактор, сопутствующий широкому распространению инклюзии: рост агрессии, ситуаций буллинга, кибербуллинга, мобинга. В инклюзивных группах 
эмоциональное напряжение и степень конфронтации могут быть более значительными, чаще возникают деструктивные конфликты. Интернет переполнен сценами школьного насилия, жестоких издевательств учащихся над своими одноклассниками, в том числе школьниками с особыми образовательными потребностями. Десятки тысяч проставленных пользователями «лайков» стимулируют стремление школьников найти очередную «жертву», снять "улетное видео», включиться в кибербуллинг. Современная «сетевая» личность ребенка или подростка получает доступ к неограниченному количеству самой разнообразной информации, в том числе той, которая может оказать на нее деструктивное воздействие. В силу анонимности и иллюзорной безнаказанности социальные сети являются идеальной средой для проявления подростковой агрессии. Для кибертравли современным школьникам необязательно быть близкими знакомыми жертвы, ведь всю информацию, которую можно использовать для издевательств, оскорблений можно получить с личной страницы человека в интернете. Педагоги, психологи, социологи, родители обеспокоены значительным ростом немотивированных вспышек агрессии школьников различного возраста

Интолерантность взрослых, учителей и родителей становится пусковым механизмом, запускающим неприятие школьниками своих «особых» одноклассников. Поэтому в ситуации инклюзии особую значимость приобретает формирование у будущих педагогов превентивной позиции, личностной установки на предупреждение различных негативных явлений: школьного насилия, буллинга, кибербуллинга, мобинга и других.

Выпускнику университета важно осознать превенцию как профессиональную ценность, помогающую выявить потенциальную «жертву» и агрессора, выделить в образовательном процессе факторы, провоцирующие конфликты. Подготовка бакалавров к превенции школьного насилия осуществлялась на пересечении двух смысловых полей: превенции и инклюзии. Для подготовки выпускников университета к принятию идеологии, этики и процедуры превенции в контексте инклюзивного обучения была проведена модернизация целей, содержания, технологий изучения 
дисциплин психолого-педагогического цикла, изменены задания производственных практик. Подготовка будущих бакалавров к превентивной деятельности в инклюзивной среде осуществлялась в процессе изучения педагогической, возрастной, социальной, специальной психологии, педагогики, конфликтологии, разнообразных курсов по выбору «Психология инклюзивного образования», «Конфликты в инклюзивном образовании».

Для эффективной организации инклюзивного образования полезна информация о способах предупреждения и конструктивного решения конфликтов. Будущий педагог должен иметь четкое представление о том, каким образом вводить «особого» ребенка в группу сверстников, как осуществлять его подготовку и подготовку одноклассников.

Стимулированию эмоционально-ценностного отношения студентов к превенции в аспекте инклюзии способствовали групповые дискуссии и диспуты. Опыт, полученный бакалаврами на практических занятиях по психологическим и педагогическим дисциплинам при обсуждении следующих тем: «Жертва» и «агрессор»: каковы их психологические особенности», «Риски и вызовы инклюзии», "Как предупредить школьное насилие в инклюзивном обучении», переносится в квази-профессиональную деятельность. Использование тренинга, игрового моделирования на практических занятиях помогало бакалаврам развивать столь необходимые в условиях инклюзии диагностические, аналитические, прогностические, конфликтологические, психотерапевтические компетенции. Квази-профессиональная деятельность бакалавров обогатила их субъективный опыт общения с разными группами детей в условиях конкретной школы, сформировала их личностную иерархию ценностей. Модернизация педагогической практики была ориентирована на стимулирование эмоционально-ценностного, конативного и операционально-деятельностного компонентов профессиональной компетентности бакалавров. Перед началом педагогической практики студентам предложили выбрать образовательные организации. Итоги сделанного выбора были предсказуемы: 79\% студентов предпочли традиционные школы 
и гимназии, только 21\% будущих учителей выбрал инклюзивные классы, в которых учатся дети с особыми образовательными потребностями. Мотивация выбора бакалавров существенно различалась. Для первой группы, типичными вариантами ответов были: «В этих классах работать труднее, не хотелось бы получить низкую отметку за практику»; «Мне кажется, что дети с ограниченными возможностями здоровья более агрессивны», «Если между учениками возникнут конфликты, я не смогу их разрешить».

Для студентов, выбравших инклюзивные классы, типичны познавательная, социальная и моральная мотивация. Среди ответов: «Интересно попробовать себя в инклюзивных классах, испытать в более трудных условиях»; «Хочу научиться работать с разными учащимися»; «Думаю, что смогу помочь детям с ООП, научить их не только математике, но и общению с одноклассниками».

В выступлениях студентов на итоговой конференции подчеркивалось, что инклюзивная среда позитивно влияет на социализацию детей, на их межличностные отношения: школьники более дружелюбны, ответственны, самостоятельны. Стимулирующий и развивающий эффект педагогической практики в инклюзивной среде оказался значительно выше, чем в традиционных классах: студенты продолжали встречаться в неформальной обстановке: организуя праздники, экскурсии, сюжетно-ролевые игры, помогая детям выполнять домашние задания. Итоги педагогической практики показали, что степень удовлетворенности студентов в инклюзивных классах оказалась существенно выше.

Практически все студенты, проводившие уроки в инклюзивных классах, отмечали, с одной стороны, перспективность инклюзии, с другой, необходимость для педагога уметь предупреждать детскую агрессию. Ограниченное время проведения педагогической практики не позволило выявить существенных изменений в личностном компоненте психологической компетентности студентов, однако обогащение конативной структуры было очевидно: расширился поведенческий репертуар бакалавров, более вариативны стали модели поведения, которые использовались при взаимодействии 
с учениками и их родителями. Наиболее существенным достижением проводимой модернизации психолого-педагогической подготовки бакалавров стало отношение к инклюзивной среде как к личной и профессиональной ценности, а также формирование действенной установки на превенцию любых вариантов школьного насилия.

\section{Literature [Литература]}

Fedotenko I.L., Ûgfel'd I.A., Âkovleva A.A. (2018), Psihologiâ konflikta v inklûzivnom obrazovanii: učebnoe posobie, Tul'skoe proizvodstvennoe poligrafičeskoe ob"edinenie, Tula.

Rangelova E. (2019), Riskove $v^{\prime \prime} v$ vzaimodejstvieto prepodavtel-student, [v:] Rangelova E. (red.), Vzaimodejstvie na prepodavatelâ $i$ studenta, vusloviâta na universitetskoto obrazovanie: teorii, tehnologii, upravlenie, EksPres, Gabrovo, s. 91-96.

Želeva E. (2019), Osobenosti navzaimodejstvieto prepodavtel-student-pacient pri podgotovkata na s specialisti po zdravni-griži, [v:] Rangelova E. (red.), Vzaimodejstvie na prepodavatelâ i studenta, vusloviâta na universitetskoto obrazovanie: teorii, tehnologii, upravlenie, Eks-Pres, Gabrovo, s. 540-545.

Zaharuk T., Čeluscinska B. (2016), Rol' prepodavatelâ v social'noj integracii $i$ bor'be protiv isklûčeniâ v processe obučeniâ studentov, [v:] Rangelova $\mathrm{E}$. (red.), Teoriâ i praktika na psihologo-pedagogičeskata podgotovka na specialista $v$ universiteta: sbornik s naučni dokladi. Vtora kniga, Eks-Pres, Gabrovo, s. 567-578. 